\title{
ANALISIS KERJA KERAS DALAM MATA PELAJARAN FISIKA DI SMAN 1 KOTA JAMBI
}

\author{
Endah Febri Setiya Rini ${ }^{1}$, Riska Fitriani ${ }^{2}$, Wita Ardina Putri ${ }^{3}$, Agnes Aktapianti Br Ginting ${ }^{4}$, \\ Maria Marisa Matondang ${ }^{5}$ \\ Program Studi Pendidikan Fisika, Universitas Jambi ${ }^{1,2,3,4,5}$ \\ Email: endahfebri9@gmail.com
}

\begin{abstract}
Abstrak
Karakter kerja keras merupakan karakter yang tidak boleh punah terlebih untuk siswa akhir kelas XII Sekolah Menengah Atas (SMA). Penelitian ini bertujuan untuk mengetahui hasil deskripsi karakter kerja keras dalam mata pelajaran fisika kelas XII MIPA di SMAN 1 Kota Jambi. Penelitian ini menggunakan pendekatan kuantitatif. Jenis penelitian yang digunakan adalah survey dengan instrumen penelitian berupa angket. Teknik pengambilan sampel dalam penelitian ini yaitu menggunakan simple random sampling. Subjek penelitian ini adalah peserta didik kelas XII MIPA 1, 2, dan 3 pada tahun ajaran 2020/2021, dengan jumlah total sampel sebanyak 60 responden. Teknik analisis data penelitian ini menggunakan program SPSS. Hasil penelitian menunjukkan bahwa angket kerja keras mata pelajaran fisika tergolong "Baik". Dengan jumlah siswa yang memiliki karakter kerja keras yang berkategori sangat baik dengan persentase 8,3\%. Sedangkan, jumlah siswa yang mendapatkan kategori baik dengan persentase 91,7\%. Penelitian ini semoga dapat memberikan kontribusi sebagai pengetahuan untuk penulis dan guru yang bersangkutan dalam upaya meningkatkan karakter kerja keras mata pelajaran fisika di SMAN 1 Kota Jambi.
\end{abstract}

Kata Kunci : Karakter, Kerja Keras, Pendidikan, Fisika.

\begin{abstract}
The character of hard work is a character that must not be vanished, especially for students at the end of class XII Senior High School. This study aimed to determine the results of the character of hard work description in physics subjects in class XII MIPA at SMAN 1 Jambi City. This study used a quantitative approach. This type of research was a survey with a research instrument in the form of a questionnaire. The sampling technique used in this study was simple random sampling. The subjects of this study were students of class XII MIPA 1,2, and 3 in the 2020/2021 school year, with a total of 60 respondents. The data analysis technique in this study used the SPSS program. The results showed that the hard work questionnaire in physics was classified as "good". The number of students who had a hard work character which was categorized as very good resulted in a percentage of $8.3 \%$. Meanwhile, the number of students who got the good category resulted in a percentage of $91.7 \%$. With this research, hopefully, it can contribute as knowledge for the writer and teacher concerned to improve the character of hard work in physics subjects at SMAN 1 Jambi City.
\end{abstract}

Key Words : Character, Hard Work, Education, Physics.

\section{PENDAHULUAN}

Pendidikan merupakan topik yang menarik untuk menjadi bahan pembicaraan. Pada saat ini, pendidikan menjadi salah satu kebutuhan pokok untuk setiap inidvidu. Sebab, pendidikan adalah langkah awal untuk meningkatkan kualitas serta keterampilan [1]. Pendidikan memegang peran yang sangat penting dalam pengembangan yang menentukan kemajuan aset bangsa [2]. Sedangkan, pendidikan juga dipandang sebagai wadah untuk melahirkan generasi yang kreatif, terampil, cerdas, produktif, berbudi baik, dan bertanggung jawab [3]. Seiring dengan perubahan dan berjalannya waktu, maju mundurnya penduduk di suatu negara dipengaruhi oleh maju mundurnya kualitas pendidikan di negara tersebut [4].

Secara umum pendidikan-pendidikan di Indonesia dilakukan stratifikasi yang terdiri atas beberapa jenjang pendidikan [5]. Jenjang pendidikan tersebut di 
antaranya adalah SD, SMP, SMA, dan Perguruan Tinggi. Pada jenjang ketiga, yaitu Sekolah Menengah Atas (SMA), siswa dituntut untuk lebih aktif serta berkarakter yang baik. Hal ini dikarenakan, tuntutan kualitas individu pada masa yang akan datang diperlukan karakter yang bagus, karena karakter merupakan kunci ataupun tombak keberhasilan seorang [6]. Inilah alasan mengapa pendidikan karakter perlu ditanamkan kepada para peserta didik [7].

Adapun aspek yang menjadi bahan penilaian dalam pendidikan karakter yaitu: kejujuran, tanggung jawab, disiplin, menghargai, peduli, berusaha untuk menjadi benar, dan memiliki daya usaha/ daya juang [8]. Sesuai dengan penguatan pendidikan karakter pada satuan pendidikan formal yang tercantum dalam PERMENDIKBUD Nomor 20 tahun 2018 yang menjelaskan bahwa penguatan pendidikan karakter merupakan tanggung jawab satuan pendidikan untuk memperkokoh karakter peserta didik melalui harmonisasi hati. Penguatan pendidikan karakter harus dilaksanakan berdasarkan nilai pancasila meliputi nilai keagamaan, kejujuran, disiplin, toleransi, bekerja keras, kreatif, kemandirian, demokratis, rasa ingin tahu, semangat kebangsaan, cinta tanah air, menghargai prestasi, komunikatif, cinta kedamaian, gemar membaca, perduli akan lingkungan, perduli lingkungan sosial, dan bertanggung jawab. Salah satu hal menarik dengan pernyataan di atas yaitu mengenai karakter bekerja keras. Salah satu karakter yang tidak boleh hilang yaitu karakter kerja keras.

Kerja keras merupakan sifat seorang individu yang pantang menyerah dan tidak mudah berputus asa dalam meraih suatu tujuan [9]. Orang yang memiliki sifat seperti ini merupakan orang yang ulet dan melakukan segala hal dengan maksimal.
Peserta didik yang bekerja keras dalam proses di dalam kelas biasanya akan selalu disiplin dalam mengerjakan tugasnya serta jika ada hambatan saat mengerjakan persoalan tidak akan mudah menyerah, melainkan akan berusaha totalitas untuk menemukan solusinya [10].

Sebelumnya pendidikan karakter dibebankan pada dua mata pelajaran saja seperti agama dan juga Penidikan Kewarga Negaraan (PKN), namun dua mata pelajaran untuk menanamkan pendidikan karakter tidaklah cukup. Sehingga, pada saat ini pendidikan karakter dibebankan kepada semua mata pelajaran termasuk salah satunya adalah mata pelajaran Ilmu Pengetahuan Alam (IPA) [11]. Mata pelajaran IPA dapat menciptakan sikap kritis dan keterampilan siswa [12]. Mata Pelajaran IPA sangat berguna dan memiliki peran yang sangat penting dalam kehidupan manusia khususnya dalam pengembangan teknologi [13].

Mata pelajaran IPA terbagi menjadi beberapa bidang, salah satunya fisika. Sikap positif dalam pembelajaran merupakan kecenderungan menerima ataupun menolak konsep atau ide bila tidak sesuai dengan pikirannya. Sikap positif belum condong kepada hal yang diharapkan [14], pada kenyataannya fisika adalah pelajaran yang dianggap sulit dan dihindari oleh kebanyakan siswa [15].

\section{Berdasarkan observasi di SMAN 1 Kota} Jambi, pada saat situasi pandemi siswa mengaku cenderung merasa kesulitan dalam mempelajari mata pelajaran fisika. Guru juga mengatakan bahwa untuk penilaian ulangan, guru harus memberitahukan informasi secara mendadak agar siswa tidak berkumpul ke satu tempat saat pelaksanaannya serta dapat mencegah kecurangan dan tindakan mencontek saat pelaksanaan ulangan. Dalam hal ini, karakter kerja keras dapat 
mempengaruhi hasil belajar siswa. Hasil penelitian ini relevan dengan penelitian yang dilakukan [16], akan tetapi yang membedakan dari penelitian ini adalah tingkatan kelas ataupun subjek penelitian yang digunakan dalam penelitian.

Tujuan Penelitian ini yaitu untuk mendeskripsikan dan mengidentifikasi mengenai karakter peserta didik, terutama karakter kerja keras dalam mata pelajaran fisika kelas XII MIPA SMAN 1 Kota Jambi. Selain itu, penelitian ini juga membahas tentang statistika deskriptif seperti modus, mean, median, serta parameter statistik lainnya. Berdasarkan pernyataan tersebut, peneliti ingin melihat bagaimana kerja keras peserta didik dalam mata pelajaran fisika. Serta dengan adanya penelitian ini, semoga dapat berkontribusi sebagai pengetahuan untuk penulis dan guru yang bersangkutan dalam upaya meningkatkan karakter kerja keras dalam mata pelajaran fisika.

\section{METODE}

Desain penelitian ini menggunakan pendekatan kuantitatif dengan metode survey. Teknik pengambilan sampel pada penelitian ini yaitu menggunakan teknik simple random sampling. Subjek penelitian ini adalah peserta didik kelas XII MIPA 1, XII MIPA 2, dan XII MIPA 3 di SMA Negeri 1 Kota Jambi pada tahun ajaran 2020/2021. Dengan sampel yang didapatkan dalam penelitian ini yaitu sebanyak 60 responden. Teknik pengumpulan data dilakukan dengan cara pemberian angket atau kuesioner.

Kuesioner yang digunakan melalui skala likert dengan lima pilihan jawaban, dimana terdapat dua macam pertanyaan berupa pertanyaan negatif dan positif, pertanyaan positif diberi skor 1,2,3,4,5 dan untuk bentuk pertanyaan negatif diberi skor $5,4,3,2,1$. Teknik analisis data pada penelitian ini menggunakan program SPSS yang selanjutnya dideskripsikan dalam bentuk narasi.

\section{HASIL DAN PEMBAHASAN}

Pada penelitian ini diambil data dari kelas XII MIPA SMAN 1 Kota Jambi. Angket yang digunakan merupakan angket kerja keras dalam mata pelajaran fisika. Penelitian ini dilakukan dengan cara menyebarkan angket.

Untuk mengidentifikasi karakter kerja keras peserta didik, peneliti menggunakan bantuan aplikasi atau software SPSS dapat berupa mean, median, modus, standar deviasi, varian, nilai minimum, dan nilai maksimum.

Selain itu, peneliti juga dapat mengidentifikasi tingkat kerja keras peserta didik menggunakan skala likert. Berikut ini adalah tabel hasil analisis data statistik deskriptif menggunakan SPSS dari data angket yang telah disebarkan, sebagai berikut:

Tabel 1. Statistik Deskriptif Angket Kerja Keras dalam Mata Pelajaran Fisika di SMAN 1 Kota Jambi

\begin{tabular}{ll}
\hline Keterangan & Kolom \\
\hline$N$ & 60 \\
Mean & 4,0833 \\
Median & 4,0000 \\
Mode & 4,00 \\
Std. Deviation & 0,27872 \\
Variance & 0,078 \\
Range & 1,00 \\
Minimum & 4,00 \\
Maximums & 5,00 \\
Sum & 245,00 \\
\hline
\end{tabular}

Berdasarkan data hasil pada Tabel 1, yaitu data angket karakter peserta didik yang didapatkan, maka dapat kita ketahui nilai standar deviasi lebih kecil dari pada mean. Apabila nilai standar deviasi lebih kecil dari pada nilai mean, maka data tersebut dapat dikatakan valid, yaitu $0,27872<$ 86,94 . 
Berdasarkan hasil data tersebut, dapat disimpulkan bahwa tingkat karakter peserta didik Kelas XII MIPA dalam bekerja keras dapat digolongkan "Baik". Namun, kita perlu meninjau kembali melalui segi skala likert.

Adapun deskripsi hasil pengelompokan data angket kerja keras dalam mata pelajaran fisika berdasarkan kategori: sangat tidak baik, tidak baik, cukup baik, baik, dan sangat baik terdapat pada tabel 2 , berikut ini:

Tabel 2. Kategorisasi Angket Kerja Keras dalam Mata Pelajaran Fisika di SMAN 1 Kota Jambi

\begin{tabular}{lcl}
\hline Interval & Persen & Kategori \\
\hline $25,0-45,0$ & 0 & Sangat Tidak Baik \\
$45,1-65,0$ & 0 & Tidak Baik \\
$65,1-85,0$ & 0 & Cukup Baik \\
$85,1-105,0$ & 91,7 & Baik \\
$105,1-125,0$ & 8,3 & Sangat Baik \\
\hline
\end{tabular}

Dari Tabel 2 terlihat bahwa jumlah siswa yang memiliki karakter kerja keras yang berkategori sangat baik dengan persentase $8,3 \%$. Sedangkan, jumlah siswa yang mendapatkan kategori baik dengan persentase $91,7 \%$. Artinya, sebagian besar atau hampir seluruh siswa di kelas XII MIPA di SMAN 1 Kota Jambi memiliki karakter kerja keras yang sudah tergolong "baik" dalam mata pelajaran fisika.

Pendidikan karakter sangat penting untuk ditanamkan pada diri peserta didik. Pendidikan karakter tidak hanya di sekolah tetapi bisa melalui apa saja, namun di era globalisasi dengan berkembangnya teknologi yang semakin canggih membuat pola hidup dan karakter siswa berubah seiring perkembangan zaman [17].

Oleh karena itu, saat ini pendidikan karakter sedang diterapkan dan ditekankan dalam dunia pendidikan. Selain itu, di era kecanggihan teknologi membuat motivasi dan keterampilan kerja keras siswa semakin teriris. Seperti perilaku yang mudah menyerah mengakibatkan mencontek adalah sebuah kebiasaan yang sudah biasa [18]. Oleh karena itu, di saat ini kita harus bijaksana dalam memanfaatkan kecanggihan teknologi untuk hal positif dengan kerja keras.

Salah satu kunci sukses dalam belajar adalah dengan keinginan yang kuat dari peserta didik untuk terus belajar. Dengan terus belajar dari kesalahan ataupun belajar dari hal baru tentunya akan meningkatkan kapasitas dan kemampuan peserta didik dalam memenuhi kompetensinya.

Dengan melakukan kerja keras dalam belajar fisika yang diiringi dengan pembelajaran hal-hal baru, peserta didik secara perlahan dapat mencapai kesuksesan dalam menjalani kegiatan pembelajaran yang ditandai dengan hasil belajar yang memuaskan.

\section{SIMPULAN}

Mengacu pada tujuan penelian dan analisis berdasarkan hasil analisis angket karakter kerja keras dalam mata pelajaran fisika kelas XII MIPA di SMAN 1 Kota Jambi, dapat dikatakan bahwa tingkat kerja keras siswa dalam mata pelajaran fisika tergolong baik. Hal ini dibuktikan dengan statistik deskriptif yang telah dicari menggunakan SPSS.

Didapatkan hasil mean sebesar 4,0833, median sebesar 4,0000, modus sebesar 4,00, standar deviasi sebesar 0,27872, rentang sebesar 0,078 , nilai minimum sebesar 4,00, dan nilai maksimum sebesar 5,00 . Hal ini juga dapat dibuktikan dengan klasifikasi atau pengkategorian dari angket karakter tersebut, bahwa terdapat 8,3\% peserta didik yang menjawab angket sangat baik dan terdapat pula $91,7 \%$ yang menjawab baik. Berdasarkan hasil angket tersebut, dapat disimpulkan bahwa peserta didik kelas XII MIPA di SMAN 1 Kota 
Jambi telah memiliki karakter kerja keras yang baik dalam mata pelajaran fisika.

\section{DAFTAR PUSTAKA}

[1] D. A. Kurniawan, Astalini, dan L. Anggraini. "Evaluasi Sikap Siswa terhadap IPA di Kabupaten Muaro Jambi”. J. Ilm. Didakt., vol. 19, no. 1, pp. 124-139, 2018.

[2] Lasmita dan L. Kartina. "The Effect of Hard Work Character on Learning Achievement in Natural Science Subject of Physics Materials in 7th Grade of SMP Negeri 2 Muaro Jambi”. J. Ilm. Pendidik. Fis., vol. 6, no. 1, pp. 15-23, 2019.

[3] D. Y. Aditya. "Pengaruh Penerapan Metode Pembelajaran Resitasi terhadap Hasil Belajar Matematika Siswa". J. SAP, vol. 1, no. 2, pp. 165-174, 2016.

[4] Rahmawati. "Strategi Pembelajaran Membaca dan Menulis Permulaan Melalui Media Kata Bergambar". $J$. SAP, vol. 1, no. 2, pp. 259-270, 2017.

[5] W. Sutomo dan V. Milyani. "Mengidentifikasi Karakter 'Menghargai Prestasi Peserta Didik Kelas VIII SMP N 5 Muaro Jambi”. Publ. Pendidik., vol. 9, no. 2, p. 110, 2019 , doi: 10.26858/publikan.v9i2.9000.

[6] N. Omeri. "Pentingnya Pendidikan Karakter dalam Dunia Pendidikan". Manag. Pendidik., vol. 9, no. 3, pp. 464 - 468, 2015.

[7] Mangamar dan M. F. Oksaputra. "Analisis Peduli Lingkungan Siswa Kelas VIII E dan VIII I SMPN 1 Kota Jambi”. J. Profesi Kegur., vol. 5, no. 2, pp. 137-140, 2019.

[8] Y. Darma, U. D. Susanty, dan D. Fitriawan. "Pendidikan Karakter dalam Pembelajaran pada Mahasiswa Calon Guru Matematika". J. SAP, vol. 3, no. 2, pp. 110-115, 2018.

[9] G. Winandika dan A. N. Aziza.
"Upaya Meningkatkan Kerja Keras dan Prestasi Belajar IPA Kelas IV pada Materi Gaya Menggunakan Metode Eksperimen". J. PANCAR, vol. 1, no. 2, pp. 21-30, 2017.

[10] N. Sari, Y. Putri, N. Jannah, dan T. Puspitasari. "Hubungan Kerja Keras dan Sikap Siswa dalam mata Pelajaran IPA". Sci. Educ. J., vol. 3, no. 2, pp. $101-112,2019$.

[11] M. Khusniati. "Pendidikan Karakter Melalui Pembelajaran IPA". $J$. Pendidik. IPA Indones., vol. 1, no. 2, pp. $204-210,2012$.

[12] N. Sari dan U. P. Dewi. "Analisis Sikap terhadap Penyelidikan IPA dan Ketertarikan Berkarir di Bidang IPA di SMPN 3 Batanghari". J. Dimens. Pendidik. dan Pembelajaran, vol. 8, no. 2, pp. $72-80,2020$.

[13] D. N. L. Laksana. "Miskonsepsi dalam Materi IPA Sekolah Dasar". $J$. Pendidik. Indones., vol. 5, no. 2, pp. 873 - 882, 2016.

[14] Y. A. Siregar dan Sukanto. "Hubungan Self-Efficacy dan Sikap Positif terhadap Prestasi Akademik Siswa SMK Negeri 1 Sipriok". J. Mat. Educ. Sci., vol. 3, no. 1, pp. 22 -29, 2017.

[15] Astalini dan D. A. Kurniawan. "Sikap Siswa terhadap Pelajaran Fisika di SMAN Kabupaten Batanghari”. J. Ilmu Pendidik. Fis., vol. 3, no. 2, 2018.

[16] R. Fitriani, Kholilah, E. F. S. Rini, A. Pratiwi, Maharani Rizky Ramadhanti, H. Syiarah, dan H. Safitri. "Analisis Karakter Kerja Keras Siswa Kelas XI IPA di SMAN 1 Kota Jambi". PENDIPA J. Sci. Educ. J. Sci. Educ., vol. 5, no. 2, pp. 188-194, 2021.

[17] E. Maulidah. "Character Building dan Keterampilan Abad 21 dalam Pembelajaran di Era Revolusi Industri 4.0". Pros. Semin. PGSD, 2019. 
[18] C. B. Siswati, Utomo, dan A. Muntholib. "Implementasi Pendidikan Karakter dalam Membentuk Sikap dan Perilaku Sosial Peserta Didik Melalui
Pembelajaran Sejarah di SMA PGRI 1 Pati Tahun Pelajaran 2017/2018". Indones. J. Hist. Educ., vol. 6, no. 1, pp. 1-13, 2018. 